\title{
Meloidogyne ethiopica and Meloidogyne arenaria parasitizing Oxalis corniculata in Brazil
}

\author{
Cristiano Bellé $^{1}$ • Tiago Edu Kaspary ${ }^{2}$ - Juliane Schmitt ${ }^{3} \cdot$ Paulo Roberto Kuhn $^{4}$
}

Received: 20 February 2016 / Accepted: 18 July 2016 / Published online: 21 July 2016

(C) Australasian Plant Pathology Society Inc. 2016

\begin{abstract}
Meloidogyne ethiopica and Meloidogyne arenaria were identified morphologically and via isozyme profiles of female nematodes extracted from Oxalis corniculata root samples collected from plantations in the municipality of Caiçara, Rio Grande do Sul State, Brazil. To the best of our knowledge, this is the first report of $M$. ethiopica and $M$. arenaria parasitizing $O$. corniculata in Brazil.
\end{abstract}

Keywords Occurrence · Identification · Root-knot nematodes $\cdot$ Weed $\cdot$ Alternate host

Oxalis corniculata (creeping woodsorrel) is a cosmopolitan species found in tropical and temperate areas, occurring as a weed in many countries worldwide. This weed is recorded from tea plantations in Sri Lanka, Indonesia and Taiwan; corn, bean, potato and rice plantations in Japan, India, Indonesia and Brazil; and grasslands in Australia and Brazil (Eiten 1963; Holm et al. 1977). It is recorded in coffee plantations in El Salvador, India, Kenya, Mexico, Tanzania, Venezuela, and Brazil and can negatively impact agricultural production.

Cristiano Bellé

crbelle@gmail.com

1 Universidade Federal de Pelotas - UFPel, Pelotas, RS 96010-900, Brazil

2 Universidade Federal do Rio Grande do Sul - UFRGS, Porto Alegre, RS 91540-000, Brazil

3 Universidade Federal de Santa Maria - UFSM, Santa Maria, RS 97105-900, Brazil

4 Empresa de Pesquisa Agropecuária e Extensão Rural de Santa Catarina - EPAGRI, Mondaí, SC 89893-000, Brazil
It is also present in greenhouses, nurseries, and garden areas causing losses of plants (Hodi et al. 2014).

O. corniculata is a host of insects and pathogens, including nematodes (Mônaco et al. 2009). Nematode species of the genus Meloidogyne are pathogens that cause production and quality losses in several crops in Brazil and all over the world (Machado 2014). M. javanica Chitwood, M. incognita Chitwood, M. arenaria Chitwood, M. enterolobii Yang; Eisenback, and M. ethiopica Whitehead are the main species attacking plants in Brazil. There are few studies describing the incidence of Meloidogyne in O. corniculata (Dabaj and Jenser 1990). However, there are reports of its infestation by M. hapla in Hungary (Martin 1958) and M. javanica in South Africa and Brazil (Ponte et al. 1996).

$O$. corniculata plants with roots infected by the nematode were detected and collected in a cultivated area in the municipality of Caiçara, north region of Rio Grande do Sul, Brazil $\left(-27^{\circ} 16^{\prime} 55^{\prime \prime} \mathrm{S},-53^{\circ} 27^{\prime} 51^{\prime \prime} \mathrm{W}\right)$. At the time of sample collection in November 2015, plants exhibited decreased size, yellowing of leaves, and roots with an elevated number of galls associated with the presence of necrosis (Fig. 1). Root tissues parasitized by the nematode were obtained from these plants. Approximately 40 adult milky white females were obtained in oviposition, twenty were used for perineal pattern observation and were prepared according to the technique described by Taylor and Netscher (1974). The remaining females were macerated to determine the esterase isoenzyme phenotype using a horizontal electrophoresis system (Carneiro and Almeida 2001). M. javanica (Est. J3) females were used to study enzymatic patterns. Second-stage juveniles $\left(\mathrm{J}_{2}\right)$ were retrieved through the extraction of $5 \mathrm{~g}$ of processed roots, according to the technique of Hussey and Barker (1973) and then counted in Peters chambers. Microscope slides of perineal patterns were deposited in the Universidade Federal de Santa Maria (UFSM) Collection, Rio Grande do Sul, Brazil. 
Fig. 1 Symptoms of root-knot nematode (Meloidogyne sp.) parasitism on roots of Oxalis corniculata (arrows indicate nematode galls)

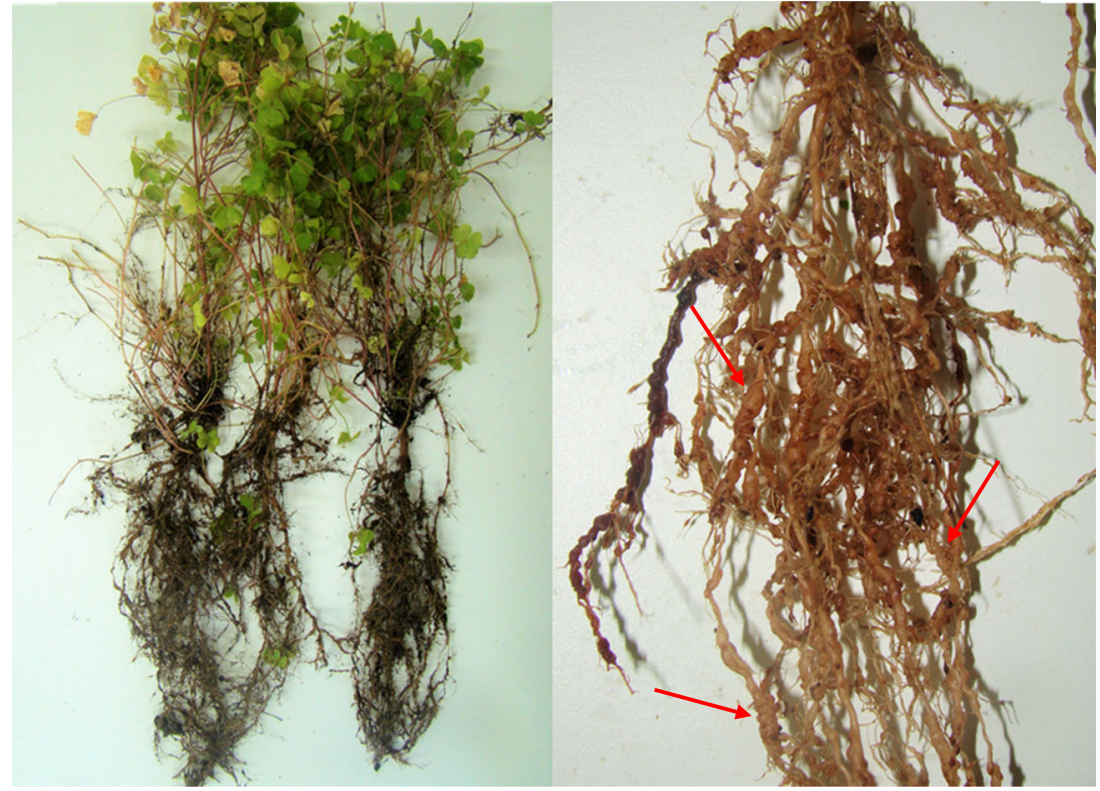

A high population level of Meloidogyne was found in the root system of sampled $O$. corniculata plants, varying from 975 to 1545 eggs $+\mathrm{J}_{2}$ of nematodes for each $5 \mathrm{~g}$ of the sampled roots.

Molecular analysis was performed to confirm nematode species identification. DNA was extracted from individual females and the mitochondrial DNA region between COII and 16S was amplified and sequenced using primers C2F3 (5'-GGTC AATGTTCAGAAATTTGTGG-3') and 1108 (5'-TACC TTTGACCAATCACGCT-3') (Powers and Harris 1993).

Both perineal esterase phenotypes patterns were consistent with those described of $M$. ethiopica and M. arenaria (Hunt and Handoo 2009; Carneiro and Almeida 2001). The esterase phenotypes consisted of two bands for $M$. arenaria Est. A2 (Rm: 1.26 and 1.36) and three bands for M. ethiopica Est. E3 (Rm: 0.91, 1.15, and 1.30) (Fig. 2). The perineal patterns for M. arenaria (Fig. 2a) appeared as oval near round and no punctations near the tail terminus. Some striae were forked and short and irregular near the lateral lines. M. ethiopica (Fig. 2b) showed perineal patterns moderately high to high dorsal arch; thick and separated striae from mild to wavy and undivided lateral field.

A fragment of approximately $1108 \mathrm{bp}$ and $1635 \mathrm{bp}$ was produced, for $M$. arenaria and $M$. ethiopica respectively. The sequence obtained was deposited in GenBank under the accession number KU841772 which was $100 \%$ identical to sequences of $M$. arenaria (GenBank JQ446377.1, KF993637.1 and AY635610.1) and KU852490 which was 99 to $100 \%$ identical to sequences and $M$. ethiopica (GenBank AY942848.1, KM042847.1, and KM042848.1) respectively.

To the best of our knowledge, this is the first report of M. ethiopica and M. arenaria parasitizing $O$. corniculata in Brazil. Both of these root-knot nematode species are pathogens of crops in Brazil and the presence of host weed species can aid in their maintenance and population build-up in fields. M. ethiopica and M. arenaria are polyphagous, parasitizing
Fig. 2 Esterase phenotypes (right) and perineal patterns (left) for Meloidogyne spp. collected from Oxalis corniculata roots in southern Brazil. Isolate of Meloidogyne javanica (Est. J3) was used as reference. a, M. arenaria (Est. A2) and b, M. ethiopica (Est. E3)
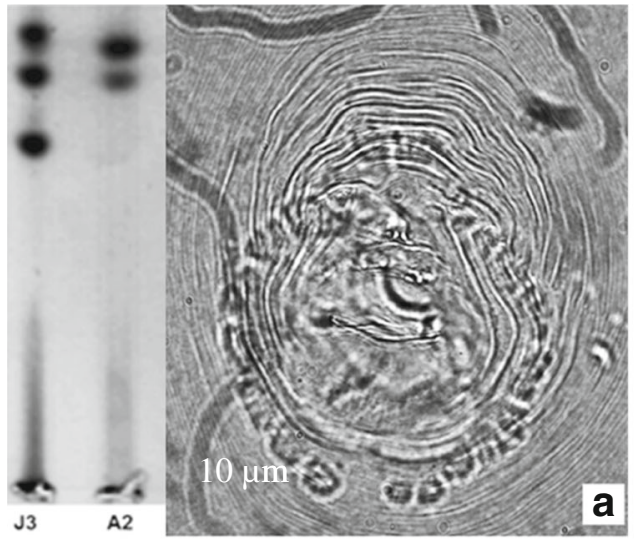

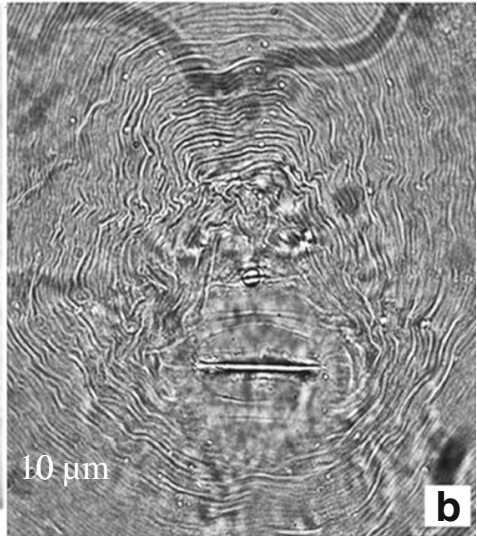


major crops such as soya, corn, tobacco, sugarcane and vegetables. Therefore, control of this weed is important to manage root-knot nematode impacts in commercial crops.

\section{References}

Carneiro RMDG, Almeida MRA (2001) Técnica de eletroforese usada no estudo de enzimas dos nematoides de galhas para identificação de espécies. Nematol Brasileira 25:35-44

Dabaj KH, Jenser G (1990) Some weed host-plants of the northern rootknot nematode Meloidogyne hapla in Hungary. J Nematol Mediterr 18:139-140

Eiten G (1963) Taxonomy and regional variation of Oxalis section Corniculatae. I. Introduction, Keys and synopsis of the species. Am Midl Nat 69:257-309

Hodi AM et al (2014) Role of Oxalis corniculata L. as plant virus reservoir with special regard to Tomato Spotted Wilt Virus (TSWV-RB) strain occurrence in rock-wool cultivation in Hungary. In: 26th German Conference on weed Biology an Weed Control. 239-243
Holm LG, Plucknett DL, Pancho JV, Herberger JP (1977) The World's Worst Weeds. Distribution and biology. University Press of Hawaii, Honolulu

Hunt DJ, Handoo ZA (2009) Taxonomy, identification and principal species. In: Perry RN, Moens M, Starr JL (eds) Root-knot Nematodes. CABI, Wallingford, pp. 55-97

Hussey RS, Barker KR (1973) A comparison of methods of collecting inocula of Meloidogyne spp., including a new technique. Plant Dis Rep 57:1025-1028

Machado ACZ (2014) Current nematode threats to Brazilian agriculture. Curr Agric Sci Technol 20:26-35

Martin GC (1958) Root-Knot Nematodes (Meloidogyne spp.) in the Federation of Rhodesia and Nyasaland. Nematologica 3:332-349

Mônaco APA et al. (2009) Reação de espécies de plantas daninhas a Meloidogyne incognita Raças 1 e 3, a M. javanica e a M. paranaenses. Nematol Bras 33:235-242

Ponte JJ, Holanda YCA, Aragão ML (1996) Adendo ao catálogo de plantas hospedeiras de Meloidogyne no Brasil. Nematol Bras 20:73-81

Powers TO, Harris TS (1993) A polymerase chain reaction method for identification of five major Meloidogyne species. J Nematol 25:1-6

Taylor DP, Netscher C (1974) An improved technique for preparing perineal patterns of Meloidogyne spp. Nematologica 20:268-269 